\title{
Occurrence of Trichinella spp. in rats on pig farms
}

\author{
Ewa Bilska-Zając ${ }^{1, A-F}{ }^{\oplus}$, Mirosław Różycki ${ }^{1, A-D \oplus}$, Ewelina Antolak ${ }^{1, B}{ }^{\oplus}$, Aneta Bełcik ${ }^{1, A-C} \odot$, \\ Katarzyna Grądziel-Krukowska ${ }^{1, B-C}$, Jacek Karamon $^{1, B, E \oplus}$, Jacek Sroka $^{2, C-D \oplus}$, Jolanta Zdybel ${ }^{1, A-B, D \oplus}$, \\ Tomasz Cencek ${ }^{1, D-F} \oplus$ \\ ${ }^{1}$ National Veterinary Research Institute, Puławy, Poland \\ ${ }^{2}$ Institute of Rural Health, Lublin, Poland \\ A - Research concept and design, B - Collection and/or assembly of data, C - Data analysis and interpretation, \\ $D$ - Writing the article, E - Critical revision of the article, F - Final approval of article
}

\begin{abstract}
Bilska-Zając E, Różycki M, Antolak E, Bełcik A, Grądziel-Krukowska K, Karamon J, Sroka J, Zdybel J, Cencek T. Occurrence of Trichinella spp.
\end{abstract} in rats on pig farms. Ann Agric Environ Med. 2018; 25(4): 698-700. doi: 10.26444/aaem/99555

\begin{abstract}
Introduction. The highest risk of trichinellosis for human is considered in eating meat products containing live larvae, mostly from wild boars or pigs. Spreading of Trichinella spp. may occur in various ways, one of which is transmission by vectors. The rat is considered to be the most common vector for Trichinella parasite. The population of rats living on pig farms can play an important role in maintaining or spreading the parasite to other animals.

Objective. The aim of presented survey was to investigate the occurrence of Trichinella spp. in rats on farms with pigs infected with this parasite.

Materials and method. From pig farms selected for study, the muscles of collected rats were investigated by magnetic stirrer digestion method to assess occurrence of Trichinella in the rat population. Isolated Trichinella parasites were identified under stereomicroscope and multiplex PCR were performed for species identification.

Results. Rats infected with Trichinella spp. were discovered on three of five investigated pig farms. The mean extent of invasion in rats from the studied farms was $23.33 \%$. The calculated medium intensity of invasion was 4.09 lpg (larvae per gram) (SD 5.41). All larvae of Trichinella discovered from rats were identified as T.spiralis.

Conclusions. The results obtained indicate that in farms with a high prevalence of Trichinella invasion in pigs there are very likely to be found rats infected by this nematode. This suggests possibility to maintain the invasion in herd and spread into neighborhood farms.
\end{abstract}

\section{Key words \\ Trichinella spp., rats, pig farm}

\section{INTRODUCTION}

Based on data from the National Institute of Public Health - National Institute of Hygiene (NIPH - NIH), 956 cases of human trichinellosis were reported in Poland in the years 2000-2012. Trichinellosis is caused by parasites from the Trichinella genus. Humans can be infected by the ingestion of muscle tissue containing live Trichinella larvae. Due to the high risk in humans, the most important as the source of infection in Central Europe is represented by the meat of wild boars and pigs. Both animals represent two different environments: sylvatic and synanthropic. Sylvatic environment, forest areas have suitable conditions for the spread of this parasite. A very important reservoir for Trichinella spp. are populations of wild boar (Sus scrofa) and red fox (Vulpes vulpes) which are large biomasses for this parasite. Moreover, the prevalence of the parasite in wild boars and foxes is growing, consequently causing the spread of Trichinella to other hosts. In the synanthropic environment, the most important hosts are pigs. The occurrence of the parasite in pigs in Poland from last decades is decreasing. However, every year from a few up to dozens of cases of infected swine are still noted. Transfer of the parasite from

Address for correspondence: Ewa Bilska-Zając National Veterinary Research Institute, Puławy, Poland, Partyzantów Avenue, 57, 24-100 Puławy, Poland e-mail: biliwkazdejchwili@vp.pl

Received: 29.10.2018; accepted: 03.11.2018; first published: 29.11.2018 one environment to another, occurring under favourable conditions, may represent a danger, especially when the parasite is introducing to a pig farm. Illegal feeding of pigs by wastes (remains of meat containing Trichinella spp. larvae) could be the cause of infection on farms. The other way of introducing the parasite to pigs is transmission by vectors. One of these could be the brown rat (Rattus norvegicus), especially on pig farms without proper control and presenting a low level of sanitary conditions [1]. The access of rats to a pig farm may cause the possibility of transfer of different pathogens to the herd, among them the Trichinella parasite. However, these animals can also transmit pathogens outside the farms. Trichinella infections were most commonly found in rats originating from swine farms in which trichinellosis were detected [2]. Rats caught near garbage dumps also were found to be infected by this nematode [3]. In Poland, studies of Trichinella spp. prevalence in rats were conducted several decades ago by Ramisz et al. [4], and there is no current data on the invasion of this host.

\section{OBJECTIVE}

The aim of presented survey was to investigate the occurrence of Trichinella spp. in rats from Trichinella infected pig farms. 


\section{MATERIALS AND METHOD}

The study was carried out in five traditional pig farms in which Trichinella spiralis infection occurred in swine. The farms were located in the Kujawsko-Pomorskie, Podlaskie, Pomorskie, Wielkopolskie and Zachodnio-Pomorskie provinces. The farms were not applying controlled housing conditions. All five herds present indoor an breeding system, without access to the sylvatic environment. The buildings on each farm were old style, divided into several boxes, in which from 1-30 animals were kept. The buildings were not fenced and other animals (cats, dogs or rodents) have access to them. Moreover, the evidences of rodent livings (faeces) were noticed in each of chosen farms. In each farm, after discovering Trichinella infected pigs, an epidemiological investigation was started. Among other actions, the chemical eradication of rodents was carried out. The carcasses of eradicated rats were collected for the research. In total, 180 rat carcasses were collected. The number of animals kept on each farm and the number of obtained rat's carcasses from each herd is presented in Table 1.

Table 1. Trichinella infected pig farms where rats were examined

\begin{tabular}{lcccccc}
\hline Farm & Year & $\begin{array}{c}\text { Province/ } \\
\text { Locality }\end{array}$ & $\begin{array}{c}\text { No. of } \\
\text { pigs in } \\
\text { herd }\end{array}$ & $\begin{array}{c}\text { No. of } \\
\text { infected } \\
\text { pigs in herd }\end{array}$ & $\begin{array}{c}\text { No. of } \\
\text { rats } \\
\text { collected }\end{array}$ & $\begin{array}{c}\text { Gender ratio } \\
\text { male/female }\end{array}$ \\
\hline Farm A & 2013 & $\begin{array}{c}\text { Kujawsko- } \\
\text { Pomorskie/ } \\
\text { Mogilno }\end{array}$ & 36 & 18 & 56 & $23 / 33$ \\
\hline Farm B & 2013 & $\begin{array}{c}\text { Podlaskie/ } \\
\text { Wysokie } \\
\text { Mazowieckie }\end{array}$ & 83 & 24 & 13 & $3 / 10$ \\
\hline Farm C & 2014 & $\begin{array}{c}\text { Zachodnio- } \\
\text { Pomorskie/ } \\
\text { Łobez }\end{array}$ & 14 & 6 & 21 & $4 / 17$ \\
\hline Farm D & 2016 & $\begin{array}{c}\text { Pomorskie/ } \\
\text { Tczew }\end{array}$ & 366 & 11 & 50 & $17 / 33$ \\
\hline Farm E & 2015 & $\begin{array}{c}\text { Wielkopolskie/ } \\
\text { Wągrowiec }\end{array}$ & 32 & 2 & 10 & $2 / 8$ \\
\hline & & & & & & \\
\hline
\end{tabular}

Larvae isolation. The collected rat carcasses were skinned and eviscerated, and muscle samples from the legs and intercostal muscles were taken for examination. 10-25 gram of muscle sample were examined by artificial digestion, according to EU Regulation 2015/1375, Annex I, Chapter III [5]. Isolated larvae were counted under a stereomicroscope and then preserved in $96 \%$ ethyl alcohol at $-20^{\circ} \mathrm{C}$ until DNA extraction. Extensity and intensity of infection were calculated. Intensity of invasion (lpg) were calculated on the basis of the number of larvae found in 1 gram of the muscle sample. For statistical analysis, $\mathrm{Chi}^{2}$ and Mann-Whitney test were used.

Species identification. Five larvae from each sample were separately examined and used for isolation of DNA. The DNA was extracted from each larva separately. From samples containing less than five larvae, all of them were used for isolation. DNA was isolated and purified with the use of DNA IQtm System kit (Promega, USA). Purified DNA samples were stored at $-20^{\circ} \mathrm{C}$ until their use in PCR.

The PCR reactions were performed in a thermocycler (TProfessional, Biometra) according to the protocol of the EU Reference Laboratory for Parasites (EURLP) 'Identification of Trichinella Muscle Stage Larvae at the species level by Multiplex PCR' [6]. The PCR products were separated electrophoretically through $1.5 \%$ agarose gels and stained with ethidium bromide. The DNA bands in gel were visualized under UV light. For every PCR running, negative (nuclease free water) and positive (reference Trichinella larvae ISS3, ISS2 or ISS13 DNA from EURLP) controls were used.

\section{RESULTS}

From five pig farms investigated in the study, in three of them (farms A, B and C) Trichinella larvae were found in the muscles of collected rats. In total, 21 rats were found to be positive for Trichinella larvae (Tab. 2).

Table 2. Prevalence of Trichinella spp. in rats

\begin{tabular}{lccc}
\hline Farm & $\begin{array}{c}\text { No. of infected rats } \\
\text { (male/female) }\end{array}$ & $\begin{array}{c}\text { Percentage of } \\
\text { infected rats }\end{array}$ & $\begin{array}{c}\text { Intensity of invasion[lpg] } \\
\text { mean (range) }\end{array}$ \\
\hline Farm A & $17(4 / 13)$ & $30.36 \%$ & $4.25(0.02-23)$ \\
\hline Farm B & $1(1 / 0)$ & $7.69 \%$ & 1.78 \\
\hline Farm C & $3(1 / 2)$ & $14.29 \%$ & $3.95(0.8-6.38)$ \\
\hline Farm D & 0 & - & - \\
\hline Farm E & 0 & - & - \\
\hline Total & 21 & $23.33 \%$ & 4.09 \\
\hline Male total & 6 & $12.24 \%$ & $3.49(0.46-5)$ \\
\hline Female total & 15 & $11.45 \%$ & $4.34(0.02-23)$ \\
\hline
\end{tabular}

The total extent of invasion was $11.66 \%$. The mean extent of invasion in rats from farms A, B and C was $23.33 \%$. The highest extensity of invasion was in farm $\mathrm{A}-30.36 \%$, subsequently in farm $\mathrm{C}-14.29 \%$ and in farm B $-7.69 \%$. The calculated medium intensity of invasion was $4.09 \mathrm{lpg}$ (SD 5.41). The highest intensity of invasion $-23 \mathrm{lpg}$, was calculated in one rat from farm A (Tab. 2). The extent of invasion in male rats was $12.24 \%$ and in female rats $-11.45 \%$. However, the difference between both groups was not statistically significant $\left(\mathrm{Chi}^{2}=0.218\right.$; $\mathrm{p}$-value $\left.=0.88\right)$. Furthermore, there were no statistically significant differences between intensity of the invasion in groups of males and females ( $U$-value $=35.5$; p-value $=0.48$ ).

The species identification by multiplex PCR of examined in the survey larvae showed T. spiralis infection in all investigated rats.

\section{DISCUSSION}

The obtained results showed the occurrence of Trichinella parasite in rats in three from five investigated pig farms. The infected rats originated from farms in which the prevalence of Trichinella in pigs was higher than $28 \%$ (farms A, B and C). The species identification of larvae collected from rats in this survey also indicated T. spiralis infection. Similar to these findings, T. spiralis was discovered in pigs and rats in farm outbreaks in Croatia [7]. Pozio et al. [8] highlighted that this species is significantly more often discovered in both pig and brown rat populations than other species of this nematode. In Poland, T. spiralis also is dominant in pigs, but T. britovi was also discovered in a few cases [9]. However, it has to 
be highlighted that in farm outbreaks the same species of Trichinella does not always occur. For example, in Estonia, pigs infected with T. britovi were discovered, while rats in the neighborhood were infected by T. spiralis [10]. The above case indicates that these animals are not always the source of infection for pigs in a herd; however, their role as a vector transmitting the parasites cannot be ruled out.

The extensity of invasion in the analyzed rats ranged from $7.69-30.36 \%$, while the intensity of invasion was $0.02-$ $23 \mathrm{lpg}$ (average $4.09 \mathrm{lpg}$ ). In most samples, the intensity of Trichinella invasion was low $(0.02-5 \mathrm{lpg})$. Only two samples were characterized by higher intensity (15 and $23 \mathrm{lpg}$ ) - both came from rats captured on the same farm in the KujawskoPomorskie province (farm A). Similar studies have been conducted in Croatia where the problem of trichinellosis in pigs was closely related to the occurrence of rats. The extent of the invasion in rats from pig farms with trichinellosis ranged from $0.2-10.7 \%$, depending on the farm, and the average intensity was $234.4 \mathrm{lpg}(0.2-974 \mathrm{lpg})$ [7]. Leiby et al. [2], who also examined rats captured on farms on which trichinellosis occurred in pigs, found that $42.4 \%$ of them were infected with Trichinella, and the average intensity of invasion was $293.2 \mathrm{lpg}$. In both of the above cited studies, the intensity of invasion was significantly higher than that observed in the current study. These differences are probably due to a different source of infection. The suggested source of rat infection in the above studies was pork waste which was given to pigs and which also fed the rats. In the current study, there had been no previous occurrence of the trichinellosis in the studied herds, and the high number of infected animals (at the same time) and the low intensity of invasion indicate a single access to the source (which was not very high in Trichinella) for a large number of swine. Incidental contamination of the feed with the carcass of an infected rat could result in the invasion of only a very few pigs. This allows the supposition that the feed was contaminated by a bigger amount of fragmented, minced meat containing a relatively small number of Trichinella larvae. In the case of farm A, it was suspected that the source of the parasite for pigs was the carcass of illegally hunted wild boar added to the feed, but this was not officially confirmed. Similar findings were obtained in analyzing farms $\mathrm{B}$ and $\mathrm{C}$, where a high extent with low intensity of Trichinella invasion in pigs was also observed. Therefore, it is unlikely that rats were the source of invasion of those pigs.

Similar analyzes were carried out in pig herds by Murrell [11], pointing to the large role of rats, not as the primary source of invasion, but as a factor supporting the existence of invasion in the herd, and a vector that allows the invasion to spread outside the breeding facilities. The study conducted by Smith et al. [12] also confirms the role of rats in spreading
Trichinella invasion from infected pig's farms to neighbouring herds.

\section{CONCLUSIONS}

The presented study emphasizes that high prevalence of Trichinella in pigs on farms with poor sanitary condition predisposes to the appearance of invasion by rats. As Polish pig production of $95 \%$ on small farms with up to 35 animals in a herd, and where biosafety rules are not always properly applied, the risk of occurrence of Trichinella invasion in rats could be relatively high.

\section{Acknowledgement}

The results described in the article are a part of the $\mathrm{PhD}$ thesis by Ewa Bilska-Zając entitled 'Analysis of the genetic structure of Trichinella nematodes occurring in Poland and its application in epidemiological investigations'.

\section{REFERENCES}

1. Sattmann H, Prosl H. History of early research on trichinellae and trichinelloses. Wien Tierarztl Monat. 2005; 92(12): 283-7.

2. Leiby DA, Duffy CH, Murrell KD, Schad GA. Trichinella spiralis in an agricultural ecosystem - transmission in the rat population. J Parasitol. 1990; 76(3): 360-4.

3. Thi NV, Nguyen VD, Praet N, Claes L, Gabriel S, Huyen NT, Dorny $\mathrm{P}$. Trichinella infection in wild boars and synanthropic rats in northwest Vietnam. Veterinary Parasitology. 2014; 200(1-2): 207-11.

4. Ramisz A, Balicka-Laurans A, Urban E. [Studies on the incidence of Trichinella in rats in the industrial animal husbandry establishments]. Wiad Parazytol. 1979; 25(5): 565-8.

5. Commission Implementing Regulation (EU) 2015/1375 of 10 August 2015 laying down specific rules on official controls for Trichinella in meat

6. Zarlenga DS, Chute MB, Martin A, Kapel CM. A multiplex PCR for unequivocal differentiation of all encapsulated and non-encapsulated genotypes of Trichinella. Int J Parasitol. 1999; 29(11): 1859-67.

7. Stojcevic D, Zivicnjak T, Marinculic A, Marucci G, Andelko G, Brstilo M, Pavo L, Pozio E. The epidemiological investigation of Trichinella infection in brown rats (Rattus norvegicus) and domestic pigs in Croatia suggests that rats are not a reservoir at the farm level. J Parasitol. 2004; 90(3): 666-70.

8. Pozio E, Rinaldi L, Marucci G, Musella V, Galati F, Cringoli G, Boireau P, La Rosa G. Hosts and habitats of Trichinella spiralis and Trichinella britovi in Europe. Int J Parasitol. 2009; 39(1): 71-9.

9. Cabaj W. [Wild and domestic animals as permanent Trichinella reservoir in Poland]. Wiad Parazytol. 2006; 52(3): 175-9.

10. Jarvis T, Miller I, Pozio E. Trichinella britovi in domestic pig--a case report. Acta Vet Scand. 2002; 43(2): 131-4.

11. Murrell KD, Stringfellow F, Dame JB, Leiby DA, Duffy C, Schad GA. Trichinella spiralis in an agricultural ecosystem. 2. Evidence for natural transmission of Trichinella spiralis from domestic swine to wildlife. J Parasitol. 1987; 73(1): 103-9.

12. Smith HJ, Anzengruber A, DuPlessis DM. Current status of trichinosis in swine in the Atlantic provinces. Can Vet J. 1976; 17(3): 72-5. 